\title{
Experts challenge claims for space tourism
}

Helen Pearson, Mojave

The sun was fierce and expectations were sky high when SpaceShipOne took flight over the windswept Mojave desert early on Monday morning. The rocket has become the first privately funded, manned spaceship to skim the edge of space. But experts say its creators may have to go back to the drawing board if they want a craft capable of ferrying passengers into orbit.

Enthusiasts claim that an era of affordable, commercial space travel will be ushered in by the $\$ 20$-million spacecraft, which was designed by aerospace engineer Burt Rutan and his company Scaled Composites, and backed by Microsoft co-founder Paul Allen. The launch is also Rutan's stepping stone towards the Ansari X prize, a \$10-million

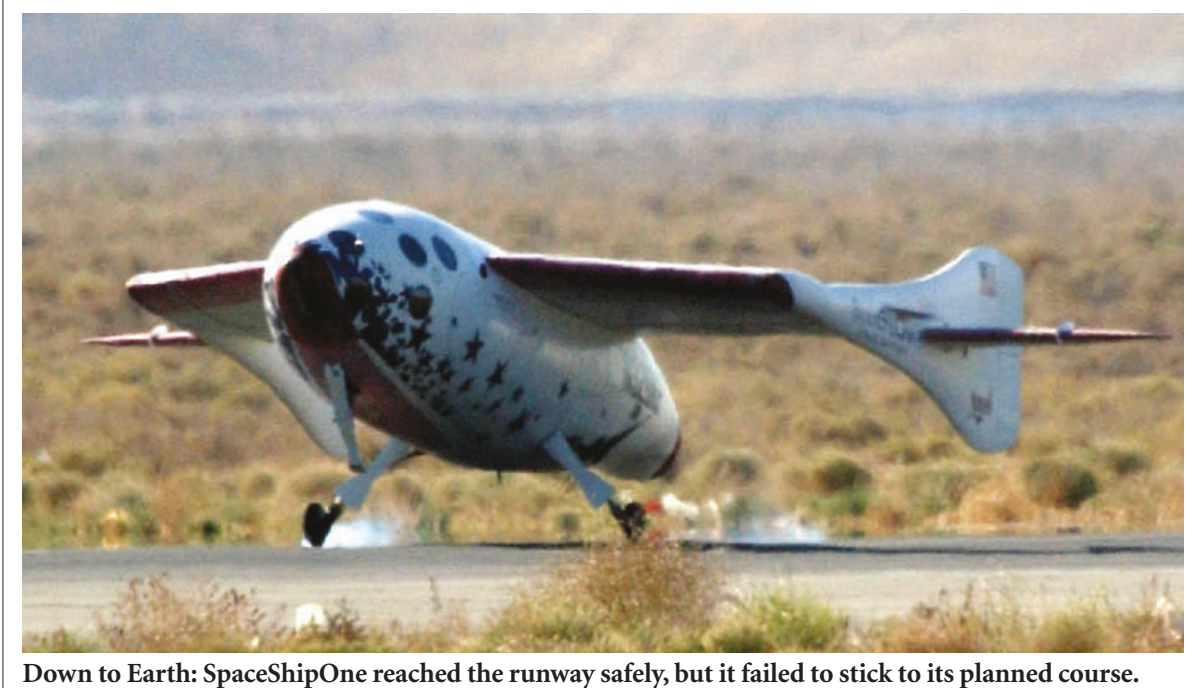

Down to Earth: SpaceShipOne reached the runway safely, but it failed to stick to its planned course.

jackpot for the first privately financed rocket to send three passengers, or an equivalent weight, up to a height of 100 kilometres twice within a fortnight.

Although aerospace engineers have applauded Rutan's feat, they say there are still numerous technological and financial hurdles to be overcome. "It's a wonderful achievement — but whether it leads to long term space tourism is really questionable," says Jerry Grey, director for aerospace policy at the American Institute of Aeronautics and Astronautics in New York. "It is insignificant in the overall scheme of space flight," says space-history expert Roger Launius of the National Air and Space Museum in Washington DC.

On 21 June, SpaceShipOne piggy-backed

\section{RNA therapy beckons as firms prepare for clinical trials}

\section{Erika Check, Washington}

Biotechnology companies are edging closer towards taking a promising gene-silencing technique called RNA interference (RNAi) into clinical trials.

The technique can be used to inhibit viruses in animals, such as hepatitis in mice. But it has not yet been tested in people, although companies are consolidating their intellectual property positions and filling their bank accounts in the hope of launching clinical trials, possibly this year.

RNAi relies on a natural mechanism in which animal cells target and destroy foreign genetic material (see Nature 425, 10-12; 2003). Injecting small pieces of RNA into a cell seems to trigger the destruction of any pieces of RNA matching the injected sequence. This creates the enticing prospect of 'knocking down' expression of RNA in viruses such as HIV or on a carrier aeroplane to about 15 kilometres. Once released, it fired its custom-built hybrid engine, powered by a solid mix of synthetic rubber and nitrous oxide, or laughing gas, to reach 100 kilometres. This fuel cocktail is less flammable than the Space Shuttle's mix of liquid oxygen and liquid hydrogen, making for a safer, though less punchy, blast.

The craft re-entered the atmosphere by flipping up the back part of its wings into a high-drag configuration that is designed to ensure it sinks slowly without generating too much heat. This is different from conventional rockets, which use a computerized system to keep them at the right angle during descent. Ninety minutes after take off, pilot Mike Melvill landed safely back on Earth.

Still, not everything went as planned. The rocket crested at about 100.1 kilometres, but Rutan hoped to reach nearly 110 kilometres. It strayed over 30 kilometres off course when it re-entered the atmosphere. And the ship also touched down with a dent in its tail.

To reach continuous orbit some 300-400 kilometres above Earth will take top speeds that are eight times as fast as that of SpaceShipOne and an exponential leap in efficiency and energy, experts say.

Rutan would not confirm whether he plans to build orbital craft. But some of the other 26 X-prize contenders, and a few companies outside the competition, are already testing prototype spaceships with orbital flight in mind. SpaceX in El Segundo, California, for example, is scheduled to put a \$30-million US Department of Defense satellite into orbit on a prototype verticaltake-off rocket later this year. hepatitis, as well as correcting neurological problems or muscle disease.

One firm pioneering the approach was founded by biologist and Nobel laureate Philip Sharp of the Massachusetts Institute of Technology. His company, Alnylam Pharamceuticals, based in Massachusetts, went public in May, raising \$30 million.

Alnylam merged last year with Ribopharma, a company based in Kulmbach, Germany, which owns a European patent on RNAi. It is working in diseases such as macular degeneration (progressive vision loss) and aims to test an RNAi technology in AIDS patients with the condition next year.

Benitec, a firm based in Queensland, Australia, has emerged as Alnylam's main rival. Last year, the US Patent and Trademark Office granted Benitec a patent that seems to cover a large range of clinical applications of RNAi. And the firm has just acquired the company Avocel, founded by Stanford geneticist Mark Kay. Co-founder Sara Cunningham says the company hopes to be listed on the US NASDAQ stock exchange by the end of the year.

Benitec also plans to fund a clinical trial for geneticist John Rossi at the City of Hope in Duarte, California. Earlier this month, Rossi said he hoped to begin as early as this July. His trial will aim to treat children infected with HIV. The children's bone-marrow stem cells will be removed and treated with an RNAi molecule. The cells will then be implanted back into the children. It is hoped that the treated cells will resist HIV infection better than untreated cells. This could be the first RNAi clinical trial to be submitted to the US Food and Drug Administration. 